\title{
Effect of a tumour-derived lipid-mobilising factor on glucose and lipid metabolism in vivo
}

\author{
ST Russell' and MJ Tisdale*,I \\ 'Pharmaceutical Sciences Research Institute, Aston University, Birmingham B4 7ET, UK
}

Treatment of ex-breeder male NMRI mice with lipid mobilising factor isolated from the urine of cachectic cancer patients, caused a significant increase in glucose oxidation to $\mathrm{CO}_{2}$, compared with control mice receiving phosphate buffered saline. Glucose utilisation by various tissues was determined by the 2-deoxyglucose tracer technique and shown to be elevated in brain, heart, brown adipose tissue and gastrocnemius muscle. The tissue glucose metabolic rate was increased almost threefold in brain, accounting for the ability of lipid mobilising factor to decrease blood glucose levels. Lipid mobilising factor also increased overall lipid oxidation, as determined by the production of ${ }^{14} \mathrm{CO}_{2}$ from $\left[{ }^{14} \mathrm{C}\right.$ carboxy] triolein, being $67 \%$ greater than phosphate buffered saline controls over a $24 \mathrm{~h}$ period. There was a significant increase in $\left[{ }^{14} \mathrm{C}\right]$ lipid accumulation in plasma, liver and white and brown adipose tissue after administration of lipid mobilising factor. These results suggest that changes in carbohydrate metabolism and loss of adipose tissue, together with an increased whole body fatty acid oxidation in cachectic cancer patients, may arise from tumour production of lipid mobilising factor.

British Journal of Cancer (2002) 87, 580 -584. doi:I0.1038/sj.bjc.6600493 www.bjcancer.com

(c) 2002 Cancer Research UK

Keywords: cachexia; lipid mobilising factor; glucose and lipid metabolism

Loss of whole body fat is a prominent feature of cancer cachexia, with losses of up to $85 \%$ being reported (Fearon, 1992) in lung cancer patients, who had lost $30 \%$ of their pre-illness stable weight. Most studies suggest that loss of fat arises as a result of an increased lipolysis, together with increased whole body fatty acid oxidation. Thus increased plasma concentrations of glycerol, free fatty acids (FFA) and triglycerides were observed in a heterogeneous group of cancer patients with an average loss of $13 \%$ of their original body weight (Legaspi et al, 1987). Basal fatty acid turnover was elevated by $25 \%$ above that for controls, and was found to be similar to the rate observed for patients with severe burns. Lipolysis was increased by $40 \%$ in patients in whom complete triglyceride hydrolysis without re-esterification was observed, and there was a $20 \%$ increase in fatty acid oxidation.

Upregulation of catabolism, rather than defects in anabolism, appear to be most important in the loss of lipid from human adipose tissue in cancer cachexia. Thus Thompson et al (1993) have shown a two-fold increase in the relative level of mRNA for triglyceride lipase, while the relative levels of mRNA for lipoprotein lipase (LPL) and fatty acid synthase were not significantly different between cancer patients and controls. This suggests that cytokines such as tumour necrosis factor- $\alpha$ (TNF- $\alpha$ ), interleukin- 1 (IL-1), interleukin-6 (IL-6), interferon- $\gamma$ (IFN- $\gamma$ ) and leukaemiainhibitory factor (LIF), which have been proposed to decrease adipose tissue mass by decreasing synthesis of triglycerides through inhibition of LPL (Berg et al, 1994) probably play a minor role in the loss of lipid from human adipose tissue. It therefore seems more likely that lipid mobilisation in cancer cachexia can be attributed to tumour catabolic factors, such as lipid mobilising factor (LMF), which acts directly on adipose

*Correspondence: MJ Tisdale; E-mail: M.J.Tisdale@easton.ac.uk

Received 26 February 2002; revised 24 May 2002; accepted 29 May 2002 tissue with the release of FFA and glycerol in a manner similar to that of lipolytic hormones (Beck and Tisdale, 1987). LMF has been purified from the urine of patients with cancer cachexia using a combination of ion exchange, exclusion and hydrophobic interaction chromatographies (Todorov et al, 1998). Unlike polypeptide hormones stimulating lipolysis which are basic, LMF is acidic and showed homology in amino acid sequence, electrophoretic mobility and immunoreactivity with the plasma protein $\mathrm{Zn}-\alpha_{2}$-glycoprotein (ZAG). Both LMF and ZAG stimulate adenylate cyclase in adipocyte plasma membranes in a GTP-dependent process (Hirai et al, 1998). This suggests the two factors are similar, although they may differ in glycosylation. Administration of LMF to obese mice produced a specific loss of carcass lipid, without a change in body water or nonfat mass. Oxygen uptake by interscapular brown adipose tissue (BAT) was increased threefold, providing evidence for increased lipid utilisation. Despite fat mobilisation there was a decrease in blood glucose levels. Hypoglycaemia occurs in mice bearing a cachexia-inducing tumour (MAC16), although the mechanism by which this occurs is not known (McDevitt and Tisdale, 1992).

The purpose of the present study was to investigate the effect of LMF on glucose and lipid metabolism in vivo in order to quantitate the effect on energy utilisation.

\section{MATERIALS AND METHODS}

\section{Animals}

Ex-breeder male NMRI mice $(35-40 \mathrm{~g})$ were obtained from our own breeding colony and were fed a rat and mouse diet (Special Diet Services, Witham, Essex, UK). All animal experiments followed a strict protocol, agreed with the British Home Office, and the ethical guidelines that were followed meet the standards required by the UKCCCR guidelines (Workman et al, 1998). 


\section{Radiochemicals}

$\mathrm{D}$-[ $\left[\mathrm{U}^{-14} \mathrm{C}\right]$ glucose (sp. act. $\left.11.0 \mathrm{GBq} \mathrm{mmol}^{-1}\right)$, 2-deoxy-D$\left[2,6-{ }^{3} \mathrm{H}\right]$ glucose $\left(\left[{ }^{3} \mathrm{H}\right] 2 \mathrm{DG}\right.$; sp. act. $\left.1.63 \mathrm{TBq} \mathrm{mmol}^{-1}\right)$ and 2deoxy-D-[1- $\left.{ }^{14} \mathrm{C}\right]$ glucose $\left(\left[{ }^{14} \mathrm{C}\right] 2 \mathrm{DG}\right.$; sp. act. $\left.2.072 \mathrm{MBq} \mathrm{mmol}^{-1}\right)$, were purchased from Amersham Lifesciences, (Bucks, UK). [Carboxy ${ }^{14} \mathrm{C}$ ] Triolein (sp. act. $3.8 \mathrm{GBq} \mathrm{mmol}^{-1}$ ) was from New England Nuclear (Southampton, UK).

\section{Purification of LMF}

LMF was purified from the urine of weight losing patients with pancreatic cancer using a combination of batch extraction on DEAE cellulose and hydrophobic interaction chromatography as previously described (Todorov et al, 1998). Urine was centrifuged at $3000 \mathrm{~g}$ for $10 \mathrm{~min}$ to remove particulate material and diluted with 4 vol $10 \mathrm{~mm}$ Tris. $\mathrm{HCl}, \mathrm{pH}$ 8.0. DEAE cellulose $\left(10 \mathrm{~g} \mathrm{l}^{-1}\right.$ of original urine) was then added and the mixture was stirred for $2 \mathrm{~h}$ at $4^{\circ} \mathrm{C}$. The LMF-DEAE cellulose complex was isolated by low speed centrifugation, and LMF eluted with $0.5 \mathrm{M} \mathrm{NaCl}$ in $10 \mathrm{~mm}$ Tris. $\mathrm{HCl}, \mathrm{pH}$ 8.0. Bioactivity was monitored by the release of glycerol from freshly isolated epididymal adipocytes (Beck and Tisdale, 1987). The eluate was equilibrated against PBS and concentrated to $1 \mathrm{ml}$ before further purification using a Resource-Iso HPLC column (Pharmacia Biotech, St Albans, Herts, UK) employing a decreasing $\left(\mathrm{NH}_{4}\right)_{2} \mathrm{SO}_{4}$ concentration from $1.5 \mathrm{M}$. Active fractions containing LMF eluted at $0.6 \mathrm{M}$ $\left(\mathrm{NH}_{4}\right)_{2} \mathrm{SO}_{4}$ and were desalted before use by washing five times against PBS using an Amicon filtration cell. LMF eluted mainly as a single protein band of $\mathrm{M}_{\mathrm{r}} 43000$, as determined by Coomassie blue staining of a $12 \%$ SDS polyacrylamide gel (Figure 1).

\section{Treatment of animals}

LMF ( $8 \mu \mathrm{g}$ in $100 \mu \mathrm{l}$ PBS) was administered b.d. by i.v. administation into the tail vein of ex-breeder male NMRI mice. This dose was previously shown (Hirai et al, 1998) to be effective in lipid depletion in vivo. Control animals received PBS alone. This was repeated up to $48 \mathrm{~h}$ before the effect on glucose and lipid utilisation was measured.

\section{Production of ${ }^{14} \mathrm{CO}_{2}$ from $\mathrm{D}-\left[\mathrm{U}-{ }^{14} \mathrm{C}\right]$ glucose}

Animals were injected i.p. with $50 \mu \mathrm{Ci} \mathrm{kg}^{-1}$ of $\mathrm{D}$-[U- $\left.{ }^{14} \mathrm{C}\right]$ glucose in $200 \mu \mathrm{l}$ of $0.9 \% \mathrm{NaCl}$ and placed in airtight metabolic cages into which air was pumped through solid $\mathrm{CaCO}_{3}$ to absorb any $\mathrm{CO}_{2}$. Metabolically produced ${ }^{14} \mathrm{CO}_{2}$ was trapped in glass test tubes containing $20 \mathrm{ml}$ of a mixture of ethanolamine: ethoxyethanol $(1: 4)$. At specific time intervals $(0.5,1,2,4$ and $8 \mathrm{~h}) 0.5 \mathrm{ml}$ aliquots were taken and mixed with $10 \mathrm{ml}$ Optiphase Hi-safe II (Fisher Chemicals, Leics, UK), and the radioactivity was measured in a Packard Tri-Carb 2000 CA scintillation analyser.

\section{Glucose utilisation}

Glucose utilisation by various tissues after LMF administration was determined by the 2-deoxyglucose (2DG) tracer technique (Mesazaros et al, 1987a,b), with starvation overnight and throughout the experiment, but with ad libitum water. After the overnight starvation mice were injected i.v. with $50 \mu \mathrm{Ci} \mathrm{kg}{ }^{-1}$ $\left[{ }^{3} \mathrm{H}\right] 2 \mathrm{DG}$ in $200 \mu \mathrm{l} 0.9 \% \mathrm{NaCl}$ and to determine the retention of 2-deoxyglucose-6-phosphate by the different tissues, a second i.v. injection of $5 \mu \mathrm{Ci} \mathrm{kg}^{-1}$ of $\left[{ }^{14} \mathrm{C}\right] 2 \mathrm{DG}$ was administered $35 \mathrm{~min}$ after the unjection of the tritiated deoxyglucose. The accumulation of phosphorylated metabolites of 2DG was measured in selected tissues $60 \mathrm{~min}$ after the injection of $\left[{ }^{3} \mathrm{H}\right] 2 \mathrm{DG}$. Mice were

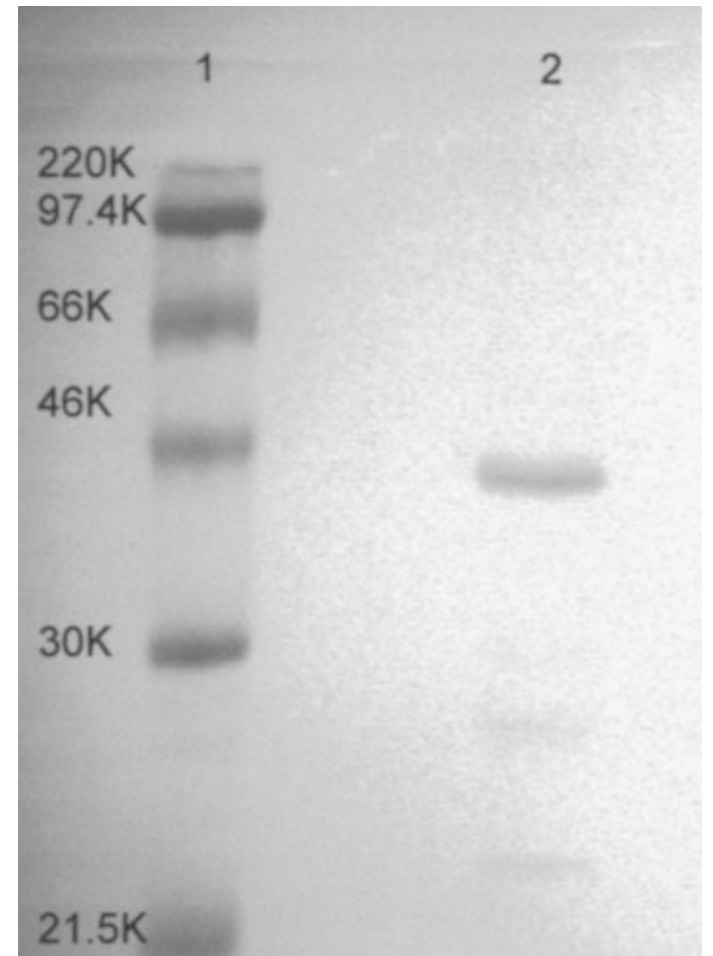

Figure I Electrophoretic separation of proteins on a 12\% SDS polyacrylamide gel. Lane I molecular weight markers; Lane 2 LMF (5 $\mu$ g protein) eluted from Resource-Iso column at $0.6 \mathrm{M}(\mathrm{NH} 4)_{2} \mathrm{SO}_{4}$.

killed by cervical dislocation and blood removed from the heart for glucose measurement by the hexokinase-glucose 6-phosphate dehydrogenase enzymatic assay (Sigma-Aldrich Co. Ltd., Dorset, UK). The concentration of radioactivity in the blood was determined on deproteinised neutralised samples with a dual ${ }^{3} \mathrm{H} /{ }^{14} \mathrm{C}$ analyser. Tissues were homogenised in ice-cold $0.5 \mathrm{~N}$ perchloric acid at the rate of $0.4 \mathrm{ml}$ per $100 \mathrm{mg}$ tissue wet weight using a Camlab 563C homogeniser (speed 8) fitted with a teflon pestle. The homogenate was centrifuged for $15 \mathrm{~min}$ at 3000 r.p.m. and the supernatant was neutralised to $\mathrm{pH} 7$ with $10 \% \mathrm{w} \mathrm{v}^{-1}$ potassium hydroxide, and the radioactivity was determined after the removal of the insoluble potassium perchlorate. This gave the total radioactivity of $2 \mathrm{DG}$ and its metabolites present in the tissue. 2DGP was removed from the neutral extract by precipitation with zinc sulphate/barium hydroxide and the difference between the total radioactivity of the neutral extract and that after removal of 2DGP represented the 2DGP content of the tissue.

Glucose utilisation was calculated from the equation (Meszaros et al, 1987a):

$$
\mathrm{Rg}=\frac{\mathrm{Cm}^{*}(\mathrm{~T})}{\mathrm{LC}_{o}^{T} \int_{C p}^{C p^{*}} \cdot \mathrm{dt}}
$$

where $\mathrm{Rg}$ is the tissue glucose metabolic rate $\left(\mathrm{nmol} \mathrm{min}^{-1} \mathrm{~g}^{-1}\right)$, $\mathrm{Cm}^{*}(\mathrm{~T})$ is the concentration of phosphorylated metabolites of 2DG in the tissue (d.p.m. $\mathrm{g}^{-1}$ ) at $\mathrm{t}=60 \mathrm{~min}, \mathrm{Cp}$ is the blood glucose $\left(\mathrm{nmol} \mathrm{ml}{ }^{-1}\right), \mathrm{Cp}^{*}$ is the concentration of $\left[{ }^{3} \mathrm{H}\right] 2 \mathrm{DG}$ in the blood (d.p.m. $\mathrm{ml}^{-1}$ ) and LC (lumped constant) is a dimensionless correction factor for discrimination against 2DG in glucose metabolic pathways. This was determined to be 0.46 in NMRI mice (Mahony and Tisdale, 1990) using the method of Ferre et al (1985). 


\section{Lipid oxidation and accumulation}

The absorption, accumulation and oxidation of an oral dose of triolein was determined using the method of Oller do Nascimento and Williamson (1986). [Carboxy ${ }^{14} \mathrm{C}$ ] triolein $(0.33 \mu \mathrm{Ci}$ in $100 \mu \mathrm{l}$ normal saline) was administered by intragastric intubation to NMRI mice previously administered either LMF or PBS. Immediately after administration animals were placed in airtight metabolic cages and expired ${ }^{14} \mathrm{CO}_{2}$ was collected over a $24 \mathrm{~h}$ period as described above. At 5 and $24 \mathrm{~h}$ some of the animals were anaesthetised and blood was collected by cardiac puncture. The complete gastrointestinal tract was removed and homogenised in $5 \mathrm{ml}$ of $3 \%$ perchloric acid. Lipids were extracted from organs and blood by the method of Stansbie et al (1976). The extracted fatty acids were dissolved in Optiphase Hi-safe II scintillation fluid and the radioactivity determined as above. Triolein absorption was calculated by subtracting the total gastrointestinal tract radioactivity from that administered.

\section{Statistical analysis}

Results are expressed as mean \pm s.e.mean. Differences were determined by one-way Analysis of Variance (ANOVA) followed by Tukey-Kramer multiple comparison test. $P$ values less than 0.05 were considered statistically significant.

\section{RESULTS}

The effect of LMF administration for $48 \mathrm{~h}$ on ${ }^{14} \mathrm{CO}_{2}$ production from $\mathrm{D}-\left[\mathrm{U}_{-}{ }^{14} \mathrm{C}\right]$ glucose is shown in Figure 2. This does not strictly measure glucose oxidation, since recycling of label and transfer to substrates such as lipids must also be considered, since they may contribute to the ${ }^{14} \mathrm{CO}_{2}$ produced. In both groups between 70 and $80 \%$ of the administered radiolabel was metabolised to ${ }^{14} \mathrm{CO}_{2}$ during an $8 \mathrm{~h}$ period. However, there was an increase in ${ }^{14} \mathrm{CO}_{2}$ production from mice administered LMF, which became significant after $2 \mathrm{~h}$, and remained above that of mice administered PBS alone over the $8 \mathrm{~h}$ experimental period.

In order to determine individual organ glucose utilisation after LMF, the 2DG tracer method was used (Meszaros et al, 1987a,b). The transport, cellular uptake and phosphorylation by hexokinase of this analogue correlate with those of glucose, but because 2DGP cannot readily be metabolised further, it can be detected in tissues containing little glucose-6-phosphatase, such as brain and muscle (Lackner et al, 1984; Jenkins et al, 1986). The tissue glucose metabolic rate $(\mathrm{Rg})$ of LMF and PBS-treated mice is shown in Figure 3. Treatment with LMF caused a significant increase in $\mathrm{Rg}$ in brain, heart, brown adipose tissue (BAT) and gastrocnemius muscle, but a decrease in $\mathrm{Rg}$ in white adipose tissue (WAT) and diaphragm. The decrease in $\mathrm{Rg}$ in WAT correlates with an increased lipid utilisation (Figure 4), although the reason for the difference between the two muscle types is not known. Since the brain is the main utilizer of glucose, the almost three-fold increase in $\mathrm{Rg}$ value observed in the presence of LMF (Figure 3) would account for the previously reported (Hirai et al, 1998) ability of LMF to decrease blood glucose levels.

The primary effect of LMF is on lipid mobilisation and utilisation through an increased rate of lipolysis (Hirai et al, 1998), and through stimulation of increased expression of mRNA for uncoupling protein 1 (UCP1) in BAT and uncoupling protein 2 (UCP2) in BAT, skeletal muscle and liver (Bing et al, 2002). The effect of LMF on the ability of mice to deal with administered lipid was investigated by intragastric intubation with $\left[{ }^{14} \mathrm{C}\right.$ carboxy] triolein $48 \mathrm{~h}$ after treatment with either LMF or PBS and the absorption into various organs was monitored over a $6 \mathrm{~h}$ period (Figure 4). There was a significant increase in $\left[{ }^{14} \mathrm{C}\right]$ lipid accumulation in plasma, liver, WAT and BAT of LMF-trea-

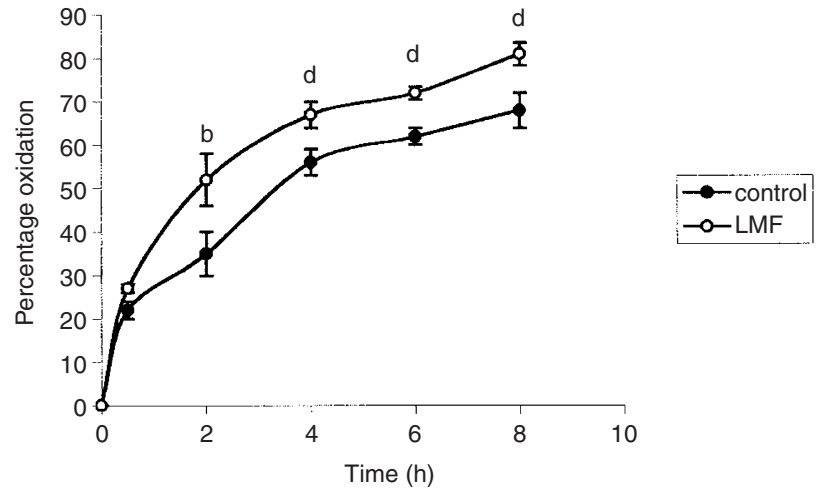

Figure 2 Production of ${ }^{14} \mathrm{CO}_{2}$ from $\mathrm{D}-\left[\mathrm{U}-{ }^{14} \mathrm{C}\right]$ glucose by NMRI mice administered either LMF for $48 \mathrm{~h}$ or PBS as described in Materials and Methods. There were 12 mice in each group. Differences from control are indicated as either ${ }^{\mathrm{b}} \mathrm{P}<0.01$ or ${ }^{\mathrm{d}} \mathrm{P}<0.001$.

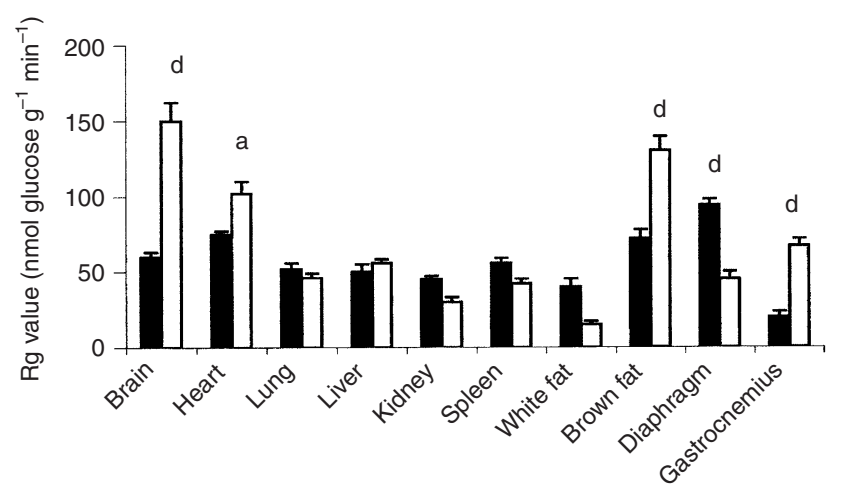

Figure 3 Tissue glucose metabolic rate $(\mathrm{Rg})$ in mice administered either PBS (closed box) or LMF (open box) as described in Materials and Methods. There were 12 mice in each group. Differences from control are indicated as either ${ }^{\mathrm{a}} \mathrm{P}<0.05$ or ${ }^{\mathrm{d}} \mathrm{P}<0.001$.

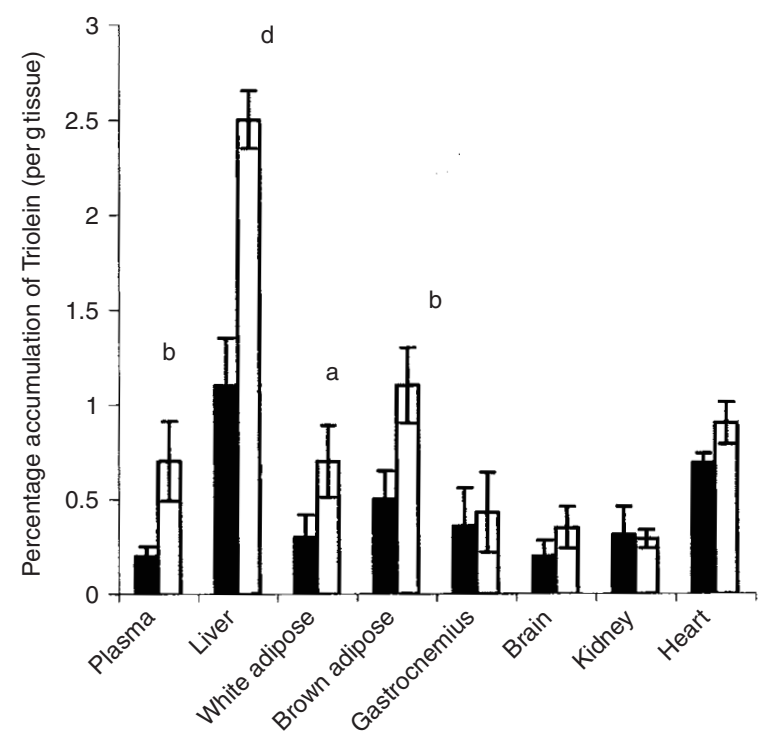

Figure 4 Tissue $\left[{ }^{14} \mathrm{C}\right]$ lipid accumulation (percentage absorbed dose per $g$ tissue over a $6 \mathrm{~h}$ period) from $\left[{ }^{14} \mathrm{C}\right.$-carboxy] triolein administered enterally by gastric intubation as described in Materials and Methods after administration of either PBS (closed box) or LMF (open box). There were 12 mice in each group. Differences from control are indicated as either ${ }^{a} p<0.05,{ }^{b} p<0.01$ or ${ }^{d} p<0.001$. 


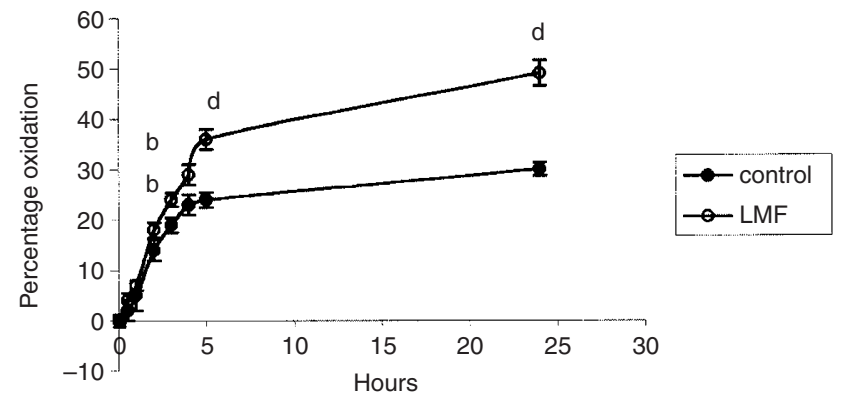

Figure 5 Production of ${ }^{14} \mathrm{CO}_{2}$ from $\left[{ }^{14} \mathrm{C}\right.$ carboxy $]$ triolein after administration of either LMF or PBS as described in Materials and Methods. There were 12 mice in each group. Differences from control are indicated as either ${ }^{b} p<0.01$ or ${ }^{d} p<0.001$.

ted mice compared with PBS controls, but no difference in gastrocnemius muscle, brain, kidney or heart. This distribution correlates with what would be expected from a decrease in lipid in plasma and WAT, and an increase in lipid in liver (Bing et al, 2002).

The rate of oxidation of $\left[{ }^{14} \mathrm{C}\right.$ carboxy] triolein to ${ }^{14} \mathrm{CO}_{2}$ for LMF and PBS-treated mice is shown in Figure 5. Lipid oxidation increased exponentially during the first $5 \mathrm{~h}$ after administration of triolein in both groups and then levelled off up to $24 \mathrm{~h}$. Animals administered LMF showed an increased rate of oxidation of $\left[{ }^{14} \mathrm{C}\right.$ carboxy] triolein during the initial phase and overall lipid oxidation was $67 \%$ greater during the $24 \mathrm{~h}$ period. This result confirms the ability of LMF to increase lipid utilization in vivo.

\section{DISCUSSION}

Loss of fat occurs when the metabolic demands on an organism are high, since fat constitutes $90 \%$ of the adult fuel reserves. Mobilisation of fat in cancer cachexia provides a fuel source for the host when the metabolic demand is high. Increased glucose utilisation by the tumour (Mulligan and Tisdale, 1991) results in an increased lactate production, resulting in an increased operation of the Cori cycle (Holroyde et al, 1975), which consumes 6 moles of ATP per mole of glucose formed. Thus cancer patients have been reported to have an increased oxidation of fat (Hyltander et al, 1991) and an increased rate of removal of infused lipids from the blood (Waterhouse and Nye, 1961). Increased utilisation of fatty acids as the preferred energy source has been observed even in the presence of high glucose concentrations (Waterhouse and Kemperman, 1971). This suggests that in the presence of certain tumours host tissues may increase their utilisation of fatty acids as an energy source. A number of studies have shown that such tumours elaborate lipid mobilising factors, which increase lipolysis in adipose tissue through the normal cyclic AMP-mediated pathway.

LMF has been extracted from the urine of patients with carcinoma of the stomach, rectum, pancreas, ovary and liver, where weight loss was established, but was absent from the urine of patients without weight loss, or from normal subjects (Todorov et al,

\section{REFERENCES}

Beck SA, Tisdale MJ (1987) Production of lipolytic and proteolytic factors by a murine tumor-producing cachexia in the host. Cancer Res 47: 59195923

Berg M, Fraker DL, Alexander HR (1994) Characterization of differentiation factor/leukaemia inhibitory factor effect on lipoprotein lipase activity and mRNA in 3T3-L1 adipocytes. Cytokine 6: 425-432
1998). This suggests that LMF may be involved in lipid depletion in cancer cachexia, although no measurements have been made on circulating levels of LMF. LMF of similar molecular weight and electrophoretic mobility was also isolated from the cachexiainducing MAC16 murine tumour and is most likely involved in lipid depletion in this model (Beck and Tisdale, 1987), since there is no evidence for cytokine involvement (Mulligan et al, 1992a). The concentration of LMF which we have employed in the present study ( $8 \mu \mathrm{g}$ per injection) was chosen based on the content of LMF in the MAC16 tumour (Todorov et al, 1998) and this concentration was previously found to be effective in depletion of adipose tissue in normal mice (Hirai et al, 1998). Maximum lipolytic activity was observed in mice bearing the MAC16 tumour when they had lost 15\% of their body weight (Groundwater et al, 1990). At this point the animals had lost $40 \%$ of their body fat (Smith and Tisdale, 1993), which is close to the value $(42 \%)$ obtained by the injection of normal NMRI mice with $8 \mu \mathrm{g}$ LMF bi-daily (Hirai et al, 1998). Many of the effects of LMF in mice are similar to those produced by the MAC16 tumour. Thus both produce hypoglycaemia (McDevitt and Tisdale, 1992), lipid depletion (Beck and Tisdale, 1987) and an increased ${ }^{14} \mathrm{CO}_{2}$ production from $\left[{ }^{14} \mathrm{C}\right]$ triolein (Mulligan et al, 1992b) indicative of an increase in lipid utilisation. Hypoglycaemia induced by LMF arises from an increased glucose consumption by the brain, heart, BAT and gastrocnemius muscle. The mechanism for the increased glucose consumption is not known, but appears to occur in a non-insulin-dependent manner (Islam-Ali and Tisdale, 2001a) and probably arises from an increased glucose transport and phosphorylation due to an increase in GLUT1 or GLUT3. LMF increases metabolic substrate utilisation in vivo. Thus overall glucose oxidation was increased by LMF, as measured by the formation of ${ }^{14} \mathrm{CO}_{2}$ from $\mathrm{D}-\left[\mathrm{U}-{ }^{14} \mathrm{C}\right]$ glucose. LMF also produced an increase in oxidation of lipid, and the increased lipid accumulation by BAT and WAT after LMF administration may be due to rapid lipid turnover in these tissues. LMF has been shown not only to initiate lipolysis, but also to prime adipose tissue towards lipolytic stimuli by increasing $\mathrm{G} \alpha \mathrm{s}$ expression with a reciprocal decrease in $\mathrm{G} \alpha \mathrm{i}$ (Islam-Ali et al, 2001b). This together with the increase in UCP1 mRNA in BAT (Bing et al, 2002) after LMF suggests a role also in the disposal of excess lipid. Large amounts of micro-droplets of lipid have been shown to be deposited in hepatocytes after LMF administration (Bing et al, 2002), suggesting that lipid is mobilised at a faster rate than it can be metabolised in BAT, and that excess lipid is stored in the liver.

The results of this study confirm that LMF stimulates oxidative metabolism in whole animals, thus accounting for the lipid depletion (Hirai et al, 1998). The similarity between the effects of LMF on fuel disposal and that seen in cancer cachexia suggests that it may be responsible for the progressive lipid depletion.

\section{ACKNOWLEDGEMENTS}

This work has been supported by Bayer Corporation, USA.

Bing C, Russell ST, Beckett EE, Collins P, Taylor S, Barraclough R, Tisdale MJ, Williams G (2002) Expression of uncoupling proteins $-1,-2$ and -3 mRNA is induced by an adenocarcinoma-derived lipid-mobilizing factor. Br J Cancer 86: 612-618

Fearon KCH (1992) The mechanisms and treatment of weight loss in cancer. Proc Nutr Soc 51: 251-265 
Ferre P, Leturgue A, Burnol A-P, Penicaud L, Girad J (1985) A method to quantify glucose utilization in vivo in skeletal muscle and white adipose tissue of the anaesthetized rat. Biochem J 228: 103-110

Groundwater P, Beck SA, Barton C, Adamson C, Ferrier IN, Tisdale M] (1990) Alteration of serum and urinary lipolytic activity with weight loss in cachectic cancer patients. Br J Cancer 62: 816-821

Holroyde CP, Gabuzda TG, Putnam RC, Paul P, Reichard GA (1975) Altered glucose metabolism in metastatic carcinoma. Cancer Res 35: 3710-3714

Hirai K, Hussey HJ, Barber MD, Price SA, Tisdale MJ (1998) Biological evaluation of a lipid-mobilizing factor isolated from the urine of cancer patients. Cancer Res 58: 2359-2365

Hyltander A, Drott C, Korner U, Sandstrom R, Lundholm K (1991) Elevated energy expenditure in cancer patients with solid tumours. Eur J Cancer 27: $9-15$

Islam-Ali BS, Tisdale MJ (2001a) Effect of a tumour-produced lipid-mobilizing factor on protein synthesis and degradation. Br J Cancer 84: 1648 1655

Islam-Ali B, Khan S, Price SA, Tisdale MJ (2001b) Modulation of adipocyte G-protein expression in cancer cachexia by a lipid-mobilizing factor. $\mathrm{Br} \mathrm{J}$ Cancer 85: $758-763$

Jenkins AB, Furler SM, Kraegen EW (1986) 2-Deoxy-D-glucose metabolism in individual tissues of the rat in vivo. Int J Biochem 18: $311-318$

Lackner RA, Challiss RAJ, West D, Newsholme AA (1984) A problem in the radiochemical assay of glucose-6-phosphate in muscle. Biochem $J$ 218: $649-651$

Legaspi A, Jeevanandam M, Starnes HF, Brennan MF (1987) Whole-body lipid and energy metabolism in the cancer patient. Metabolism 36: $958-$ 963

Mahony SM, Tisdale MJ (1990) Metabolic effects of tumour necrosis factor alpha in NMRI mice. Br J Cancer 61: 514-519

McDevitt TM, Tisdale MJ (1992) Tumour-associated hypoglycaemia in a murine cachexia model. Br J Cancer 66: 815-820

Meszaros K, Bagby GJ, Lang CH, Spitzer JJ (1987a) Increased uptake and phosphorylation of 2-deoxyglucose by skeletal muscles in endotoxin-treated rats. Am J Physiol 253: E33-E39

Meszaros K, Lang CH, Bagby CJ, Spitzer JJ (1987b) Contribution of different organs to increased glucose consumption after endotoxin administration. J Biol Chem 262: 10965 - 10970
Mulligan HD, Tisdale MJ (1991) Lipogenesis in tumour and host tissues in mice bearing colonic adenocarcinomas. B J Cancer 63: 719-722

Mulligan HD, Mahony SM, Ross JA, Tisdale MJ (1992a) Weight loss in a murine cachexia model is not associated with the cytokines tumour necrosis factor- $\alpha$ or interleukin-6. Cancer Lett 65: 239-243

Mulligan HD, Beck SA, Tisdale MJ (1992b) Lipid metabolism in cancer cachexia. Br J Cancer 66: 57-61

Oller do Nascimento CM, Williamson DH (1986) Evidence for conservation of dietary lipid in the rat during lactation and the immediate period after removal of the litter: Decreased oxidation of oral $\left[1-{ }^{14} \mathrm{C}\right]$-triolein. Biochem J 239: $233-236$

Smith KL, Tisdale MJ (1993) Increased protein degradation and decreased protein synthesis in skeletal muscle during cancer cachexia. Br J Cancer 67: $680-685$

Stansbie D, Brownsey RW, Crettaz M, Denton RM (1976) Acute effects in vivo of anti-insulin serum on rates of fatty acid synthesis and activities of acetyl-Coenzyme A carboxylase and pgruvate dehydrogenase in liver and epididymal adipose tissue of fed rats. Biochem J 160: 413-416

Thompson MP, Cooper ST, Parry BR, Tuckey JA (1993) Increased expression of the mRNA for the hormone-sensitive lipase in adipose tissue of cancer patients. Biochim Biophys Acta 1180: 236-242

Todorov PT, McDevitt TM, Meyer DJ, Ueyama H, Ohkubo I, Tisdale MJ (1998) Purification and characterization of a tumor lipid-mobilizing factor. Cancer Res 58: $2353-2358$

Waterhouse C, Nye WHR (1961) Metabolic effects of infused triglycerides. Metabolism 10: $403-414$

Waterhouse C, Kemperman JH (1971) Carbohydrate metabolism in subjects with cancer. Cancer Res 31: 1273-1278

Workman P, Twentyman P, Balkwill F, Balmain A, Chaplin D, Double J, Embleton J, Newell D, Raymond R, Stables J, Stephens T, Wallace J (1998) United Kingdom Co-ordinating Committee on Cancer Research (UKCCR). Guidelines for the welfare of animals in experimental neoplasia (second edition). Br J Cancer 77: 1 - 10 